\title{
Cultural Messages of the Borobudur Temple's Symbols Seen from Aerial Photography Media
}

\author{
Ade' Dani Setiawan \\ Faculty of Cultural Sciences, Gadjah Mada University, \\ Jalan Bulaksumur, Yogyakarta 55281, Indonesia \\ Email: adesetiawan@mail.ugm.ac.id
}

\begin{abstract}
Aerial photography depicts real images and reality requirements of the real images on scientific encoding, presenting objects clearly, accurately, without any manipulations. Accurate consideration and exact flying direction coordinate will capture objects of miles away in minutes for time is too precious too loose in the air. Aerial photography has flexibility. It can move on the physical reality, abstract reality, as well as reality which deliver messages to public. By means of aerial photography Borobudur temple can be seen as a whole to complete the familiar horizontal perspective. Borobudur temple has plenty of geometrical forms on its whole parts, i.e. diagonal lines, curves, upright lines, triangles, horizontal, cones, cubes, squares, and circles. These geometrical forms symbolize Buddhist cultural and spiritual messages. This research attempts to explicate the connections of symbols and messages on the Borobudur, its nature landscape and cultural landscape using vertical approaches as recorded in aerial photography. The explication applies semiotics theory of Roland Barthes, completed with photography theories. This explication aims to enrich the former readings fulfilled from horizontal view, in order to reveal more signs and messages carried by the physical shape of the temple.
\end{abstract}

Keywords: aerial photography; Borobudur; cultural landscape; spiritual messages; temple.

\section{Background}

Photographs depicted from high level places (air) are known as aerial photography. This technique can be taken from various high level places such as sky crappers, hills, mountains, or from airplane or helicopter. The object taken from aerial look will be wider and more flat. Aerial photography plays role as a media of reproducing object to discover grand design about the earth from above. Since the earth's face has been created, aerial photography does not change anything. Aerial photography only captures rhythm of aesthetic, sociological, and anthropological values or scientific sides of what has been reflected from the earth's surface. This also happens on earth visual design made by human. Aerial photography tries to capture information which is

Received September $19^{\text {th }}, 2010$,Revised October $29^{\text {th }}, 2013$, Accepted for publication November $8^{\text {th }}, 2013$. Copyright @ 2013 Published by LPPM ITB, ISSN: 1978-3078, DOI: 10.5614/itbj.vad.2013.4.2.8 
reflected from above so that it can be stored visually and transformed into information of image data upon arrival at the earth.

This paper will discuss how aerial photography can be used to capture earth's appearance on the Borobudur Temple's area at Magelang Regency, Central Java. The earth's appearance on the Borobudur Temple's area is the mix of natural and man-made creations. It is latter known as saujana (cultural landscape). Mountains and hills around the Kedu lowland, where the Borobudur Temple's compound is located, is the earth's appearance of natural creation. Meanwhile temples and plantation fields are part of the earth's appearance of man-made creation. The mix of creations forms certain patterns which have symbolic meanings and certain cultural messages. The messages can be interpreted after seeing the result of aerial photography on that compound.

\section{About Aerial Photography}

According to its history, aerial photography was firstly made on 1858 by a photographer from Paris named Gaspard Felix Tournachon or well known as Nadar. He used an air balloon to portray Bievre land, French. Then on 1909, the Wilbur Wright brothers made aerial photography of Centocelli town, Italy from the airplane. This achievement could be obtained after they made various efforts and experiments to discover air balloon and airplane.

Aerial photography brings a new point of view of looking at people's daily life. The media of aerial photos can expose the earth's natural design more complete as needed. Aerial photography gives human abilities to see something which cannot be seen by our naked eyes when viewed horizontally. This method is part of photography genre which is very useful for cultural and media analysis, or to identify and analyze different objects on earth.

Aerial photography is able to describe activities framed on the dynamic condition. The result of this technique can be used for studying ancient sites or to reveal phenomena of human life. There are indeed many interesting pictures resulting from the eye level angle. However, it is no less interesting when we see pictures resulting from the low angle or even from the bird eye angle. Photos taken from different angle will have different impression, as stated by Lydia Kurniawati [1].

In the past, aerial photography had showed its role as a messenger of complete and excellent visual information. Presentation of the photographers may vary according to their intuition and imagination. Moreover, some of them are based on their function and importance. We can take examples from aerial photographers who have very famous photo works at international level, such as 
Kassian Cephas, James Wallace, Bernhard Edmaier, Robert Bucknam, and William Garnett.

Aerial photography gives human abilities to see something which cannot be seen from horizontal point of view. From vertical point of view, people will get complete and thorough portrayal data information of earth surface. This can also be proven at Borobudur Temple's area. Aerial photography from this area is able to expose the forms of cultural messages which cannot be perceived clearly from horizontal point of view.

\section{$3 \quad$ Aerial Photography Technique}

Aerial photos can be taken from static or dynamic platforms. Dynamic platforms are air transportation such as airplane and helicopter. By using air transportation, the process of reading earth relief looks more complete and moves more freely towards different objects. However, there are still some boundaries which have to be followed, such as air transportation is limited by the agreement of flying route coordinates. Meanwhile, static platform is skyscraping places, such as mountains and hills. In order to portray thorough cultural messages at Borobudur Temple's area, dynamic and static platforms are used (see Figure 1).
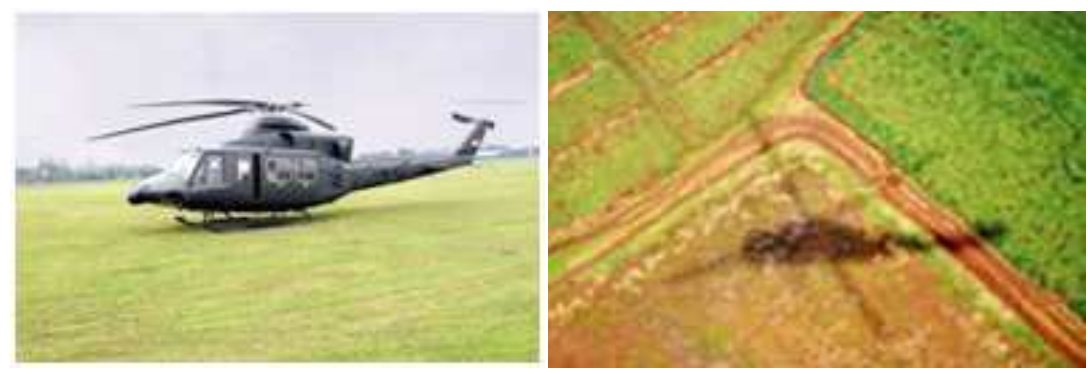

Figure 1 Helicopters as air vehicle used for aerial photography research interests Borobudur (author doc.).

From the angle of photography, the technique of aerial photography is grouped into oblique and vertical. Oblique technique is taken from oblique angle shooting $<90^{\circ}$, while vertical technique is taken by positioning the camera at a $90^{\circ}$ angle (perpendicular) from the object of shooting [2]. In visualization, oblique technique tends to result more realistic photos. The result of reading the earth relief objects can be figured as geometrical forms which still hold the earth as reality object. Shooting with vertical technique can change a reality view so that the interpretation of visual image is the identification of geometrical forms which are more abstract and surrealist. However, according 
to Lillesand and Kiefer [3], aerial photography from oblique or vertical angles can be used to result the earth objects with realistic and surrealistic impressions. Therefore, the writer uses oblique and vertical approaches.

To do the aerial photography, preparation on the ground is considerably needed. Thus, eventually the process of distant vision is started from vision from the ground or horizontally and then carried on with air transportation or vertically.

Aerial photography at Borobudur Temple's area can be functioned as a media to deliver wider cultural messages in order to preserve cultural tradition, especially for local people who are very dependent to this ancient Java structure. The reading of cultural messages at Borobudur Temple by using vertical or aerial photography will close the object itself, which is the Borobudur Temple, with the Buddhism essence. Here, the meaning of space is identical with vertical perspective. Meaning to say, vertical perspective is a high place which can be reached by human being.

From the photo sessions at Borobudur Temple's area, vision from the ground is based on photo momentum, designed form interpretation through simulation, exploration of image reflection, ground orientation which has been mapped on the earth surface as the point of interest of the temple and specifying the coordinate of Borobudur Temple as the chosen target object. To do vertical or aerial observation, several steps need to be done, such as photo interpretation, direct interpretation from above towards the chosen objects, for example objects at Borobudur Temple's area, deciding image reflection, field orientation, and portraying the chosen photo object when flying. After that, the next activity is reproducing the object as the chosen result of aerial photography.

To get the primary data of distant vision, direct observation at the surveyed filed is needed. It is meant to observe physical condition of observed area and other related situation, such as local people and their social condition. The survey is conducted for achieving interaction between aerial photography and the subject, which will be converted into object when it is taken in the air through vertical angle. It is also possible for horizontal survey to do orientation and determine points of imaginary photo targets, which can only be seen from above or in the air position. The exposition of temple objects will be better directed from distant and close vision if it is equipped with topography map and the previous research report. GPS (Global Positioning System) device is used to read the location of coordinate points from the flying route and to store data of flying route on the existed map.

The results of shooting are processed with photoshop technique in order to keep the data accurately and chronologically, as well as to maintain relation between 
the temple objects and aerial photography as one unity of scientific analysis. To prevent any failure from this analysis, aerial photography on the Borobudur Temple's area should be prepare carefully and well. Due to high cost of renting air transportation, any failure of this aerial photography will potentially lead to waste the research funds. To choose the right air transportation is part of the preparation. Based on the needs, helicopter becomes the first choice during this research because it has a very high mobility. It can maneuver to any directions, backward and forward, to left or right, fly still on one spot, or even flying low in order to close the object.

The next step is preparing the camera and its equipment. In this research, the aerial photographer brings more than one DSLR (Digital Single Lens Reflex) cameras, equipped with motor drive. Other equipments are normal, tele, zoom and wide lenses with different sizes and equipped by Giro. Other supporting equipment is optical cable which has to be connected to laptop, digital, and satellite. Aerial photography should consider the timing and weather condition. The perfect shooting time is around 07.00-09.00 in the morning. Beside the sun is in the right position to take a picture, the air is also still clean. Brightness weather is needed for aerial photography. The alternative timing would be around 15.00-17.30 in the afternoon. Apart from abovementioned condition, the photographer should have a good mental and physical preparation. Beside in a healthy condition, the photographer should be able to cooperate with the pilot. The pilot is the photographer's second eyes. Therefore, a good coordination and cooperation between them is needed. Another important element is the working system.

Safety at work is the most important factor of all. All equipments, such as seat belt should be in a good condition and the camera's properties should be taken care of from falling down and strong wind. The helicopter should in good and safe condition to fly. After passing through the fit and proper test, the process of aerial photography on Borobudur Temple's are can be carried out.

\section{$4 \quad$ Visual Texts}

The mechanism of interpreting visual language uses qualitative method which is applied on aerial photography by the process of reading objects as visual language. Within this context, Borobudur Temple and its surrounding area are considered as cultural messages or texts which can be interpreted with the background of local people's cultural practice and wider cultural context through the media of aerial photography. Texts are idea or discourse of a message which want to be delivered through media, in this case is the Borobudur Temple and its portrait. Therefore, there are at least two important steps in observing and analyzing the texts of Borobudur Temple. The first step 
is ancient culture context when the Borobudur Temple is still functioning. The second step is the present day context when the Borobudur Temple and its surrounding are interpreted as in today's context through photography.

The research to read cultural messages of Borobudur Temple from aerial photography is only one step of the whole process of interpreting and disseminating cultural messages from time to time. Initially, it started from the Buddha who delivered his sermons through various methods and media. The sermons were absorbed and understood many times until the designers and founders of Borobudur Temple gave meaning on it. In this step, the Borobudur Temple and its surrounding are the media used by designers and founders of that monument to deliver cultural messages to the pilgrims or anyone who wants to understand it.

On the second step, the cultural messages of Borobudur temple and its surrounding are portrayed and interpreted in present understandings. Aerial photography can optimally play role as documentation tool as well as media to deliver complete messages from different sides. Photography creates image from the visualization of Borobudur Temple, such as geometrical forms of three dimensional towering building which pointing above and the surface forms patterned labyrinth lines. All of them are formed in cubical shapes which are completed by decorative ornaments and carvings and the Buddha statue on the four wind directions (see Figure 2).
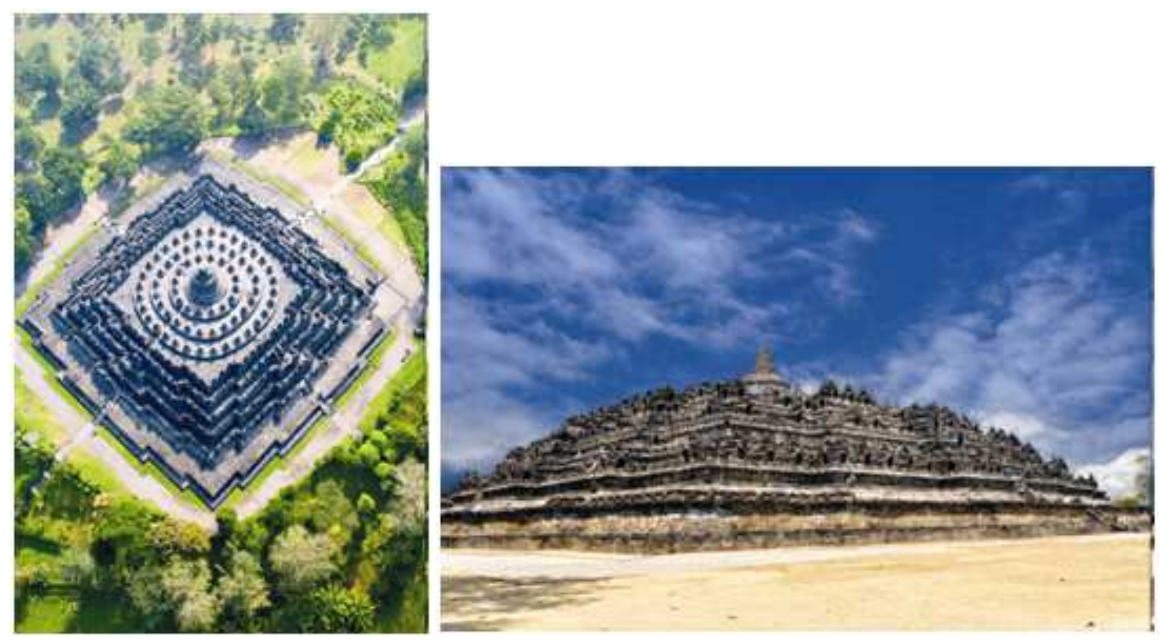

Figure 2 The visualization of Borobudur Temple, such as geometrical forms of three dimensional towering building which pointing above and the surface forms patterned labyrinth lines. (author doc.) 
Photography becomes a media to read text through production and reproduction of texts into photographic visual language. While Borobudur Temple is the messenger of cultural messages itself. Aerial photographer has a significant role in reading the Borobudur Temple as visual analysis by exposing cultural symbols which lies on Borobudur and its surrounding area.

In this paper, the researcher tries to capture cultural messages through aerial photography analysis. The research of aerial photography text of Borobudur Temple does not tend to produce new interpretation, but tends to sharpen old interpretation through bird eye view angle of Borobudur Temple that never been visually conducted. Accordingly, the research of aerial photography of Borobudur Temple will clarify previous interpretation.

From the abovementioned analysis and description, it can be concluded that the reading of cultural messages is part of cultural and media studies. It is because it always involves messages or texts (discourse) deliverance, media which produces the message, and interpreter who reads the messages. The researcher did his own photo shoots from the air. This photo shoots result in photos which are selected and then its cultural messages are interpreted based on the image on the pictures. Therefore, culture can be interpreted as institutional practice and cultural texts by understanding symbols as the process of reading moments and imaginations of geometrical objects from the objects which are latter on interpreted on visual image. Natural scenery captured in the camera is the process of photographic imagery reproduction which exposing harmony to mix understanding of spiritual energy with the Buddhism architectural context.

If it is put on the context of media studies, which is part of reciprocal relationship between sender and receiver, thus the process of this research is categorized into two sections. The first section is the researcher as the photographer of Borobudur Temple who is trying to interpret the monument and it's surrounding through his eyes and cameras. This process result in photos which is latter on selected and used as data analysis according to the researcher's framework. Within this process, the researcher has delivered new discourse or text through the media of selected photos. The second section is analyzing selected photos as part of exposing cultural messages on the Borobudur Temple and its surrounding. This process shows two relations between deliverance and interpretation of cultural messages which puts researcher as messenger (photographer as media) and interpreter (photographer as analyst). 


\section{$5 \quad$ Reading Photography Messages}

The cultural messages on the Borobudur Temple and its surrounding can be recognized from both perspectives, horizontally and vertically. Cultural message from vertical perspective provides possibilities of wider interpretation. It relates to the Buddha's philosophy which is based on the essence of transformation from material to spiritual sides as reflected on the messages at relief on Borobudur Temple walls. The meaning of cultural messages on Borobudur Temple will be completed if read on the context of natural and cultural discourse. The appearance of assumption from bottom to top, from the earth to space, makes Borobudur Temple seem flying. This is the highest achievement of Buddhist architecture which makes the object of Borobudur Temples seems real from the above perspective. This is where the spiritual meaning comes from. The vertical point of view is also able to see geometrical forms from above and the harmony of the temple and its surrounding. This image can be interpreted if it is related to the Buddhism teachings which emphasize on the harmony among human being and human being with their Gods. The Borobudur Temple is part of that harmony (see Figure 3).
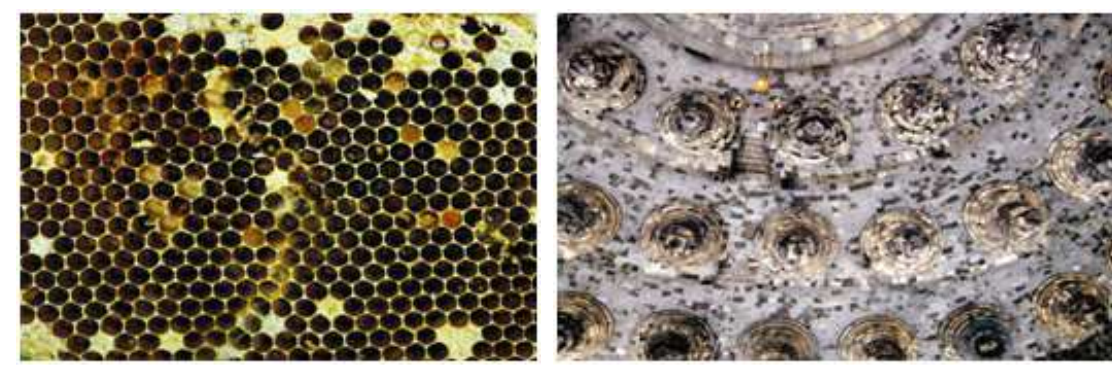

Figure 3 Interlocking honeycomb inspired at Borobudur Temple in the form of geometric and construction of stone composition. (author doc.)

The cultural messages which want to be delivered from the vertical point of view can bridge the relation between sky and earth. The description of sky life can be depicted from aerial photos on the form of geometrical visualization. Terraces are symbolized as sea waves and personified as human's struggle in dealing with various challenges of life in the world of various temptations and tests. Kempers said those challenges should be conquered in order to achieve the ultimate life which centered on the main stupa of Borobudur Temple [4]. The geometrical forms on the common structure of Borobudur Temple are four square formations with projection of each side. Each projection has geometrical forms which produce lines and creates open spaces for the interpretation of aerial views. 
Aerial photography shows relation between the Borobudur Temple and its environment. The aerial photography shows the position and meaning of Borobudur Temple towards its environment and culture. The philosophical values on this planning and architecture of Buddhist building are able to anticipate the world's changes which relates with ecological and spiritual landscape of Borobudur Temple. Harmony and balance on the cultural landscape of Borobudur from the present day's perspective is also recorded on the photographical reading. The cultural messages of Borobudur Temple help people to understand the concept of small and big universe. It is very obvious to keep and preserve symbolical meanings and spaces of Borobudur Temple. Thus, people from future generation will also understand the messages and teachings reflected on Borobudur Temple. This aerial photography shows relation between Borobudur Temple as the small universe and the world as the big universe. This concept is reflected on the harmony of Borobudur Temple at the upper and bottom world. The main stupa and other stupas become the connector between upper and bottom world.

The Borobudur Temple refers to three aspects, the geometrical forms, Lotus flower, and astronomy which support the building to deliver cultural values based on the spiritual essence of the Buddha. When the temple is put on the context of its landscape, it can be found the natural element of four basic colors: red, green, yellow and blue. These colors can be philosophically read. According to the Buddha's teachings some colors, such as red, yellow, blue, white and orange, are created before human beings were born to the earth. Those natural colors are believed to have enormous strength for people's life, such as spiritual strength, the life energy to create life motivation, and also emphatic and sympathetic feelings within human's body.

To understand the meaning of each symbol, the writer's analysis refers to Lillesand-Kiefer's theory about the image interpretation on the distant vision and Roland Barthes' theory about the semiotic analysis on the picture. The discourse of distant vision by Lillesand-Kiefer can be used to produce an image which will be seen as a mark of geometrical forms towards imagery of an object. According to Lillesand-Kiefer [3], the oblique technique of aerial photography can be used so that it produce to the earth's photos as realistic object. Therefore the writer uses the theory of oblique and vertical technique as the approach of the study.

Various cultural messages on the Borobudur Temple and its surrounding can be understood by using the image theory of distant vision by Lillesand-Kiefer and the photo's reading of semiotic symbols by Roland Barthes. Aerial photography can record clearly the cultural messages and how the Buddhism concept about the harmony of nature, people and God is shown on Borobudur's media. It is 
seen very clear the geometrical forms of symbolical cultural and spiritual messages from the Buddha in the aerial photography. Aerial photography creates image of Borobudur Temple's visualization which forms three dimensional towering building with surface forms patterned labyrinth lines. All of them are formed in cubical shapes which are completed by decorative ornaments and carvings and the Buddha statue on the four wind directions.

The universe steps of alleys can be seen on the gradual patterns. Jaques Dumarcy [5] on his books titled "Borobudur Prayer in Stone" categorized those patterns as Kamadhatu, Rupadhatu, and Arupadhatu. The Borobudur Temple is identified as geometrical forms capture in oblique and vertical photo shoots. Those geometrical forms are rectangle, triangle, circle, straight and diagonal lines, labyrinth and open space structure. It also captures geometrical image of floor pattern which is arranged with interlocking system. Besides, the same pattern also appears on the aerial photography of Borobudur cultural landscape. Rectangle is the main form of Borobudur Temple which looks intact when seeing from the context of wide Borobudur landscape. Circle is found inside the highest universe level. Those three circles which surround the main stupa can be seen vertically on the universe level of Arupadhatu. The triangle forms can be seen obliquely from Kamadhatu to the end of triangle at the main stupa on the level of Arupadhatu. The straight lines can be found at Borobudur landscape by using vertical aerial photography on the landscapes of Mendut, Borobudur and Pawon Temples. The labyrinth is found at the inside part of Rupadhatu level.

Furthermore, the form of Lotus flower is distillated on the geometrical forms of Borobudur Temple. This image will be seen when the Borobudur Temple is seen vertically from above. The impression of scattered stars is also captured on the position of stupas on the terrace of the temple.

The image of meaningful colors on the Buddhism (see the previous explanation) can be found by using static platform photo shoots. In this context, the image of colors is resulted from the static platform at Tuk Setumbu hill at Karangrejo Village, on the coordinate points GPS E 110' 10. 882' S 07' 36. 653'.

\section{Explanation to Meaning of Geometrical Forms}

The geometrical forms were actually used on Borobudur Temple since 9 century. Those forms were meant as a media to connect human with the upper universe. The forms symbolized the harmony between Borobudur Temple and the environment as one unity of cultural landscape, as well as symbolized the harmony of bottom universe trough the image of upper universe (see Figures 4 and 5). 


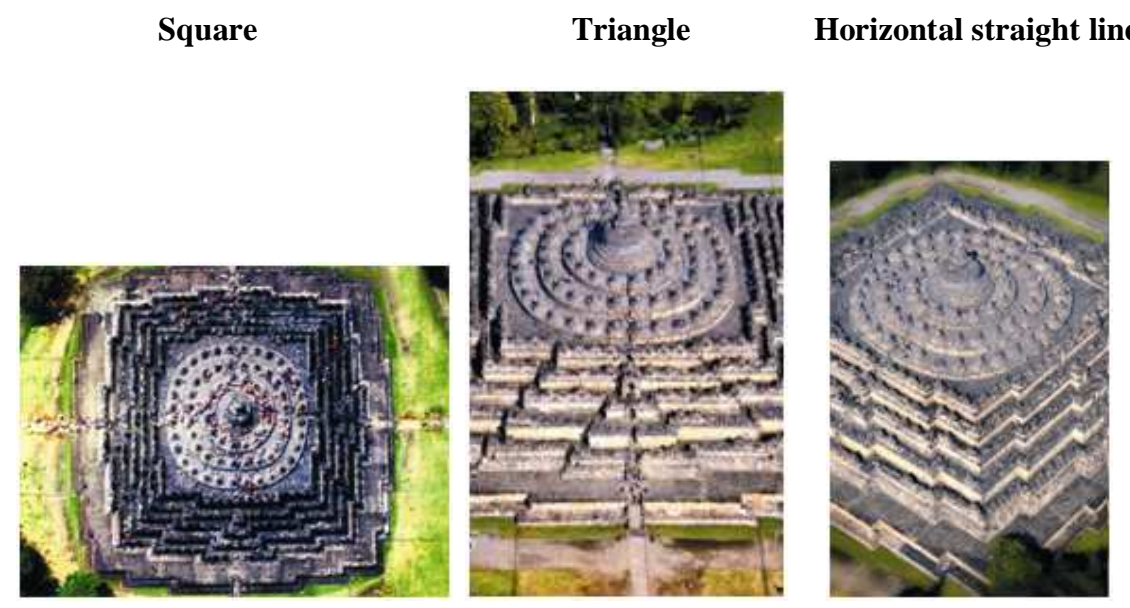

Figure 4 Geometric shapes to make a balance in the Borobudur temple and the environment as one unity of cultural landscape. (author doc.)

Rectangle forms combined with several geometri forms has created a mandala which is structured from the combination of circle, triangle, rectangle, and line forms. That combination shapes spaces which are believed having spiritual energy for Buddhist people. The geometrical forms were symbolized at the soil surface and also symbolized as a connection between the earth and the sky on the achievement of pure traveling process at the highest level in heaven.

The triangle forms in Hinduism-Buddhism teachings means a mountain. It relates to the connection between meditative mind and the God which creates pure energy. From the formation side, the mountain is interpreted as a pointed triangle which completes the transformation of the universe.

The circle inside Borobudur Temple's mandala is believed to have sacred and peaceful energies. The circle consists of concentrated circles of three levels which surround the main stupa becomes the core form of Borobudur Temple which has become the Buddha's foundation. On the procession of walking in circle to follow the path, the pilgrims open their mind to absorb sacred energy. The first circle at the lowest level means the pradaksina rotation which moves clock-wise and brings a contemplation idea. The second circle is the enhancement from contemplation level to the full concentration of spiritual values taught by the Buddha. At the highest circle which close to the main stupa, the Buddha pilgrims have closed to the upper universe to do meditation and to empty their mind to focus on prayers and getting divine enlightenment of mind. 
Labyrinth

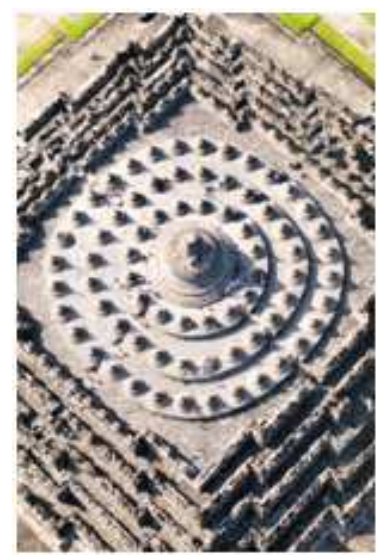

Circle

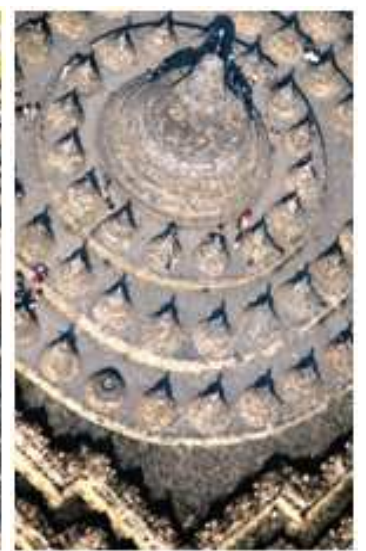

The shape of Borobudur temple is a representation of lotus flower

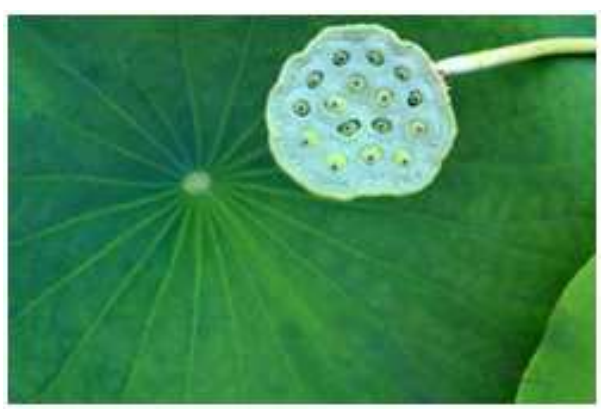

Lotus image

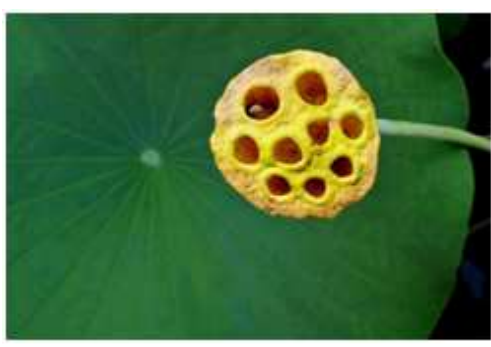

Figure 5 Geometric shapes to make a balance in the Borobudur temple and the environment as one unity of cultural landscape. (author doc.)
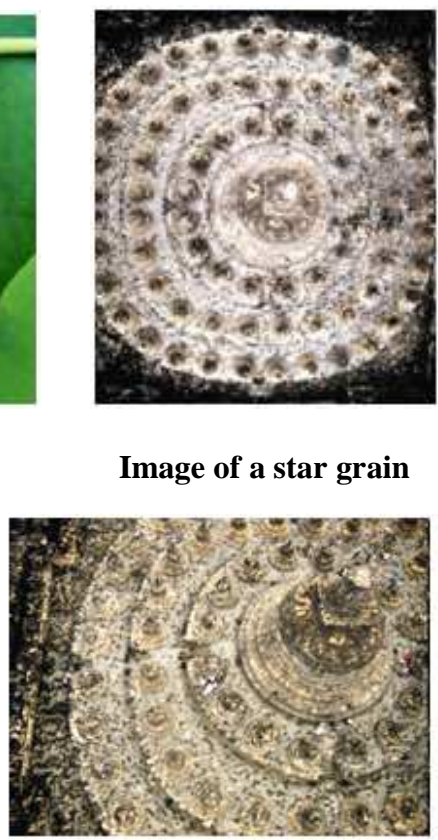

Image of a star grain 
On the visual of aerial photography there are straight and diagonal lines which connect Borobudur, Pawon and Mendut Temples (see Figure 6). According to Mahayana monks, this diagonal line is philosophically a sacred trace of old time on the ground. The sacredness will be always there when the line still connects those three temples.

\section{A : Mendut Temple \\ B : Pawon Temple \\ C : Borobudur Temple}

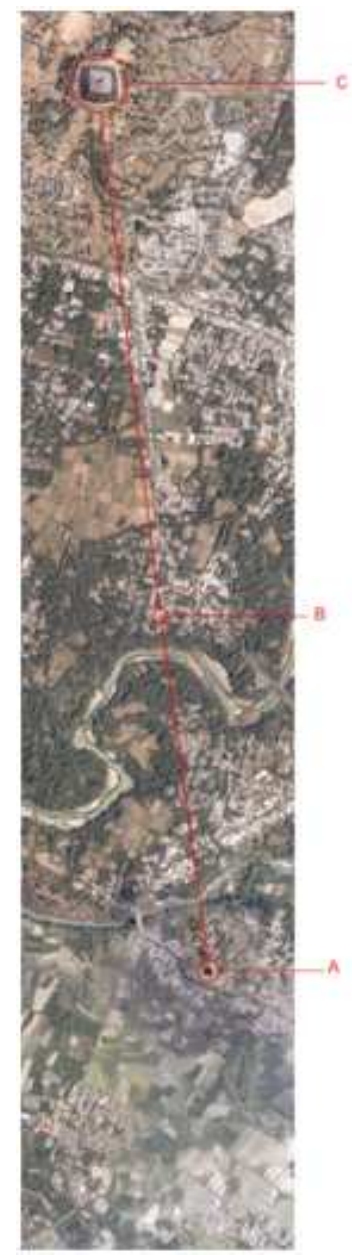

Figure 6 The visual of aerial photography there are straight and diagonal lines which connect Borobudur, Pawon and Mendut Temples. (author doc.)

The labyrinth reflected on the alley and used for pradaksina is the result of physical pilgrimage procession to achieve Bodhisattva. On the horizontal perspective, the labyrinth procession will follow the relief on Borobudur 
Temple which tells about Karmawibhangga on the Kamadhatu level (the temple's foundation). It is about the life of Buddha on various forms and the Sudhana's travelling to seek a better life. The reading of cultural messages can be done horizontally by reading the reliefs on the temple walls when walking through the alley clock-wisely as the ritual ceremony called pradaksina (while praying Tisarana prayers). On the perspective of aerial photography, the procession was captured as labyrinth forms symbolized the colors of daily life.
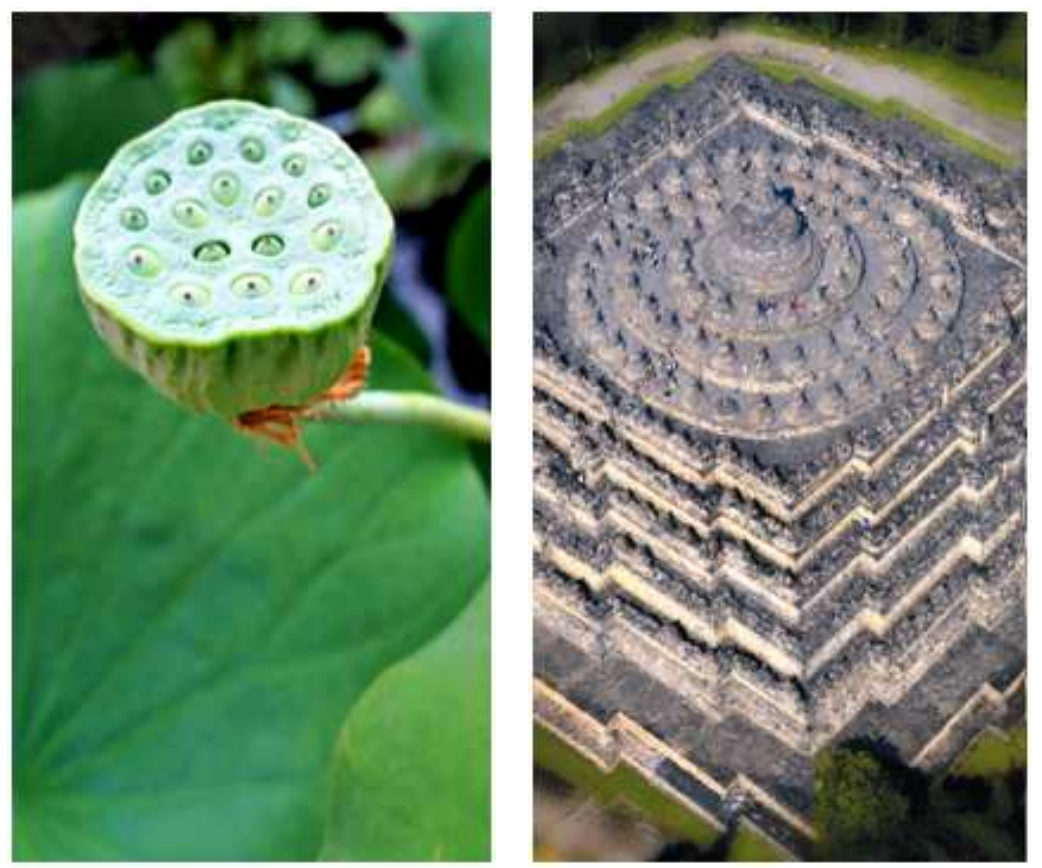

Figure 7 Flat surface of a hollow stump and overgrown with lotus seeds which are interpreted as a stupa in the terraces at levels Arupadhatu. (author doc.)

The image of lotus flower is very important to Buddha. This flower symbolizes modesty, simplicity, and compassion. The image of lotus flower on the Borobudur Temple can be captured by using bird eye angle perspective, just like the forms made from silhouette lines of the temple. Meanwhile the circle at Arupadhatu with its stupas symbolizes the hump of lotus flower which is associated with encircled stupas on the Arupadhatu level. This aerial photography show a simplified geometrical shape of the hump of lotus flower (see Figure 7). The imagery of Borobudur Temple as a lotus flower with leaves, hump and veins of leaves remind the idea that interprets Borobudur Temple and its landscape as a lotus flower on the pond. This image confirms the possibility of Borobudur Temple which was built in the middle of water environment or 
ancient lake, as what stated by Nieuwenkamp's hypothesis, a Dutch artist in 1931. The lotus flower form has been distillated. This image can be read thoroughly from the vertical photo shoots. The blooming lotus flower is meant as the Buddha's spiritualism which reminds human to be aware to their existence and duties as the God's creation which has power to organize the world as the small universe within the big universe (see Figure 8).

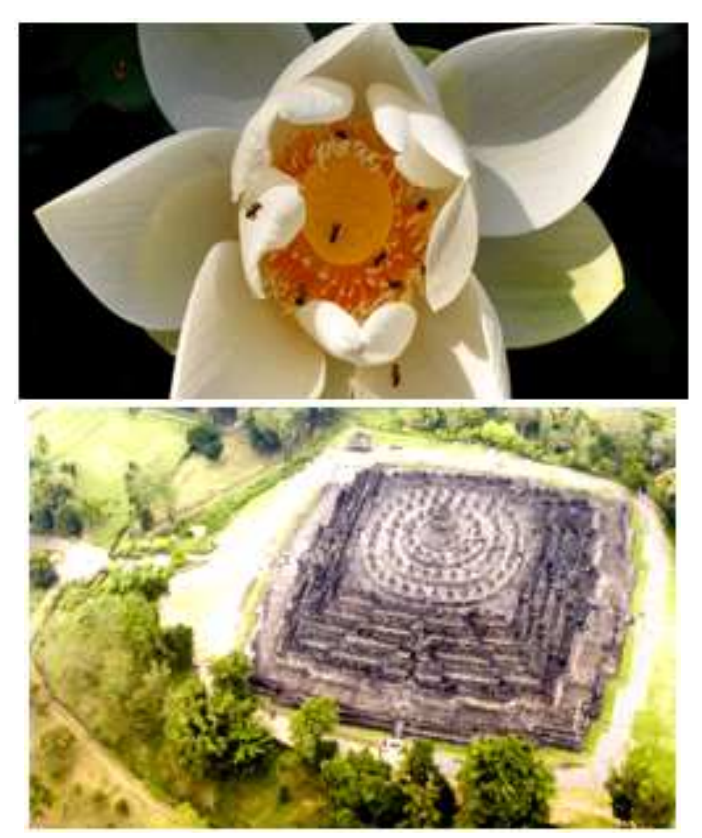

Figure 8 Nymphaeaceae lotus linkage and Borobudur. (author doc.).

The image of scattered stars on the Borobudur Temple is interpreted from the organization of stupas on the terrace of Arupadhatu level and the main stupa. The Stupa can be interpreted as receptacle which contains the remnant of the Buddha or his followers' bodies. This receptacle form then was built into a model of religious building. As the sacred building of Buddha religion, it can be understood that Borobudur Temple is symbolized by some big stupas and its building components. Moreover, those components are actually a stupa as well. However, the image of scattered stars can be connected with the use of advance astronomy on the ancient Java period. Astronomy or the knowledge of stars has been used as a media to read nature which was functioned since the planning of initial dorm of Borobudur Temple. The astronomic calculation will be very helpful on the determination of points of the Borobudur Temple's rectangle's corners. That diagonal line is believed to be able to connect the upper and bottom universe. This concept on the modern time is still used as point which 
connects the earth and the satellite in outer space and also used to read the satellite trace on its orbit. From astronomy it was known that during February, April, June and September, the Polaris stars and the cluster of stars the Urza Mayor, the Urza Minor and the Milky Way, Dubhe Merak star, Beta Arietis (Sheratan) star will be on the top of Arupadhatu and make the night sky of Borobudur Temple bright. It shows us that at that time the founders of Borobudur Temple had actually had vertical perspective toward the Borobudur Temple. The use of astronomic approach on the Borobudur Temple shows the high intelligence of the creators.

\section{Borobudur Landscape and Colors (nirmana)}

As explained on the context of Borobudur landscape, aerial photography can capture cultural messages on the symbolic forms of colors which relates to the spiritual aspect of Buddha. These colors are interpreted through visual photography. There are at least five colors used by daily life of Buddhism which appear on the aerial photography of the Borobudur landscape. One of those colors is orange. This color is used as the color of monk's cloth and flag which is written with prayers on the Buddhist ceremony (see Figure 9).

Borobudur Temple remains on its place as witness and carries on messages which glorify the unity of spiritual and natural landscape. Meaning to say, the Borobudur landscape reflects a balanced harmony between human and the compound of Borobudur Temple, among human, and between human and God, based on Buddha's teachings.

The balanced harmony is also reflected on the time and changing process which is always repeated although the color intensity of the symbols will remains a mistery for the universe as the life itself. It is explained through the passive phase of Buddha's philosophical meaning, the passive phase of temporary cessation of physical activity (the night), intense meditation or praying time in the middle of the night, before entering active phase (towards morning) as the dawn arises which is known as enlightenment phase.

The following description of Borobudur saujana and nirmana (color):

Colors on the Borobudur landscape captured by lenses in the morning can be interpreted as the end time of passive phase (rest at night) and started the active time (work at daylight). Also, symbols of silent moment to crowd moment. The change of image time is symbolized by the appearance of the sun with a burst of light that radiates to all directions of the universe, shaping configuration of color spectrum effect made by universe and decorating the walls and space of Borobudur landscape. 

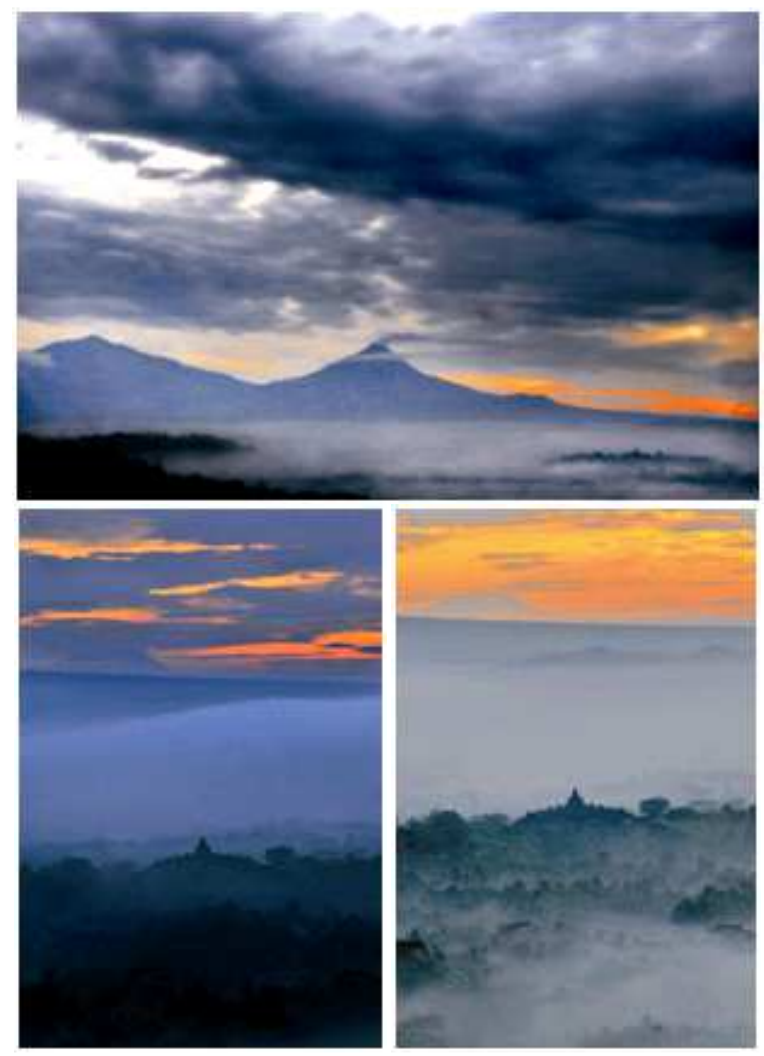

Figure 9 Buddhism believes five colors of the universe. (author doc.)

From the color point of view, Borobudur Temple has a strong relation with the nature which is also used as the background colors. The colors on the nature and its change go steady and natural because they arise based on time. However, the ability of capturing and putting natural symptoms as parts of Borobudur landscape is very special. Only sensitive people with opened senses can understand this. Thus, they chose an appropriate location to settle the Borobudur Temple as a place of worship and surrounded by majestic natural beauty.

As stated by monk Ven [6], nirmana (colors of the universe) is colors which arise in the sky and clouds like mist as part of scenic panoramic heritage for Borobudur Temple related to the Buddha's essence. This heritage comes from analysis of environmental concept which is planned thoroughly. The Buddha's teachings believe five universal colors which always arise on the universe and become basic guidance of mind and soul harmony to the sacred energy. 
The mountain as the background of Borobudur Temple on the East side becomes the representation of upper nature (divine nature).

From the aesthetical aspect, those colors give calmness and coolness; create the harmony of comfortable space. The visually photographic change creates flying effect for Borobudur Temple. It looks like lifted to the air and escapes from the earth to the sky. This visualization reflects Buddha's essence which is to seek silence and sacredness of upper nature by leaving worldly things. The reading of meaning from upper place, such as top of the mountain will bring human to see and feel silence. This faith is able to give a clean and pure energy. Natural energy is flowing by enlightened ways. It makes the pilgrims or beauty admirers have a fantasy of old time momentum (see Figure 10).
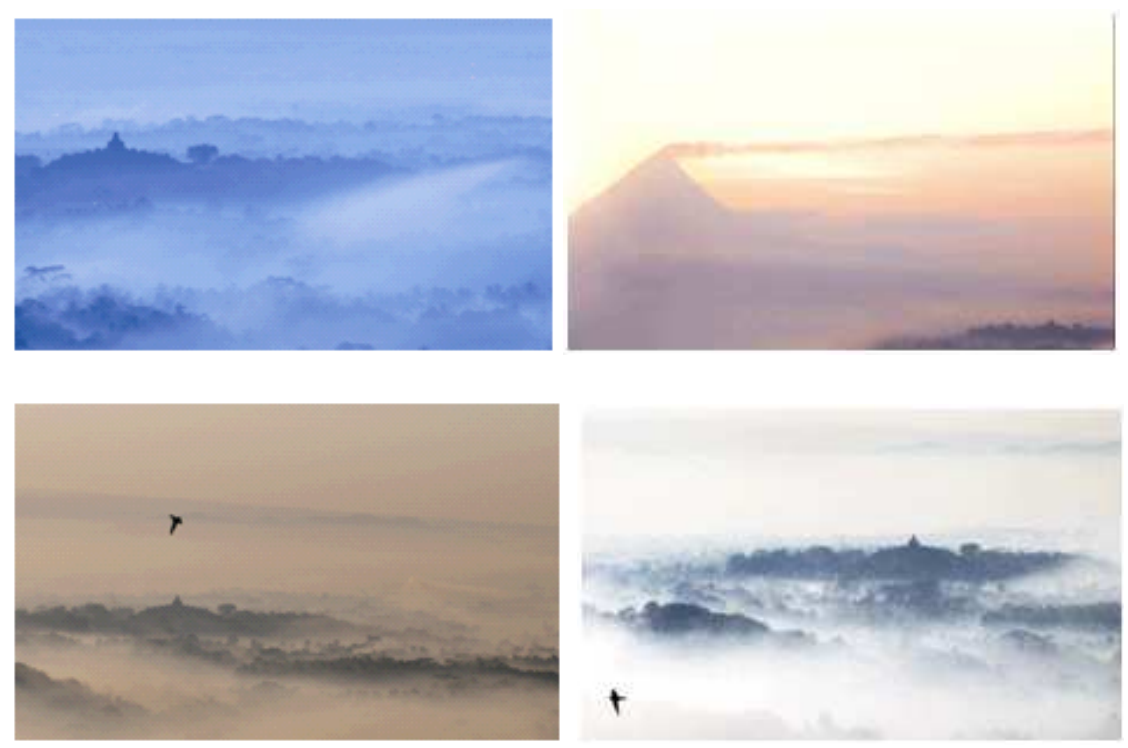

Figure 10 Borobudur saujana colors which is a scenic heritage or panorama of heirloom. Here are the photos when the change of color. (author doc.)

Other interesting part from Borobudur landscape is the use of sunlight to show reliefs on Borobudur Temple to be more vivid and real. It can be proven on certain reliefs. The sunlight had lessened the work of Borobudur Temple's carvers at that time in realizing stone artworks which is based on the power of the sunlight. Moreover, the position of the sunlight can be used to direct a figure's location and evoke effect from their creation. Sunlight which touches every temple's walls is giving energy of inspiration for these ancient Java relief carvers. For example, the picture of virupa on the southeast corner of 
Kamadhatu's legs shows only one perspective. It is very different to the picture at Rupadhatu's terrace which shows royal servants who guard the palace on the position of holding torches. On the certain time, the sunlight will touch the surface of the torchbearers' relief. So the sunlight will shine on the fire of the torch. This effect causes the relief of torchbearers can be shown perfectly, seems vivid and real. On the Arupadhatu level, the lights function is different. It is used to determine the layout of statues and its role as "mudra".

Based on the abovementioned explanation, aerial photography can show a deeper relation between Borobudur Temple and its landscape. Aerial photography affirms connection between Borobudur Temple as the small universe and the world as the big universe. From the aerial photography, the changing of environmental and cultural changes on the Borobudur Temple can be easily seen.

\section{Conclusion}

The study of aerial photography image on Borobudur Temple and its cultural landscape can be an effort of reading cultural symbols and messages carried by the temple itself. Some study results can be concluded as follows. Aerial photography affirms and visualizes geometrical forms and elements design on the temple, exposing astronomic image of scattered stars and lotus flower. On the Borobudur landscape can be found colors that affirm the existence of Borobudur Temple as the reflection of Buddha's teachings which focusing on the harmony between nature, human and God.

Aerial photography is able to capture forms which sometimes cannot be seen by horizontal perspective. Aerial photography can reproduce image through distant vision of Borobudur Temple from the open space. This ability helps writer to do vertical observation and reading as well as mapping cultural values on the visual forms which cannot be captured before. At least, the reading of cultural messages from the aerial photography at Borobudur Temple's area can affirm the temple's meaning as it is captured on other media.

\section{References}

[1] Kurniawati, L. 2007. The Adventurous Aerial Photography in the Air, Jakarta: PT. Gramedia, pp. 11-15.

[2] Paine, P.D. 1981. Aerial Photography and Image Interpretation for Resource Management, Oregon, USA: John Wiley \& Sons, Inc. Forest Management Department, School of Forestry, Oregon State University, Corvallis, pp. 31. 
[3] Lillesand, M.T. \& Kiefer, R.W. 1979. Remote Sensing and Image Interpretation, USA: Madison University of Wisconsin, pp. 31-32, 93.

[4] Kempers, A.J.B. 1976. Ageless Borobudur, Amsterdam: Servire/ Wassenaar, pp. 23, 35.

[5] Dumarcy, J. 1990. Borobudur Prayer in Stone, Singapore: Archipelago Press, pp. 155-167.

[6] Ven, N.M. 1998. The Buddha and His Teachings, Jakarta: Yayasan Dhammadipa Arama, pp. 42-44. 